\title{
EVALUATION OF PATIENTS' SATISFACTION IN TELEMEDICINE SERVICE QUALITY: A CASE STUDY ON MAIZBHANDERI FOUNDATION, FATIKCHARI, BANGLADESH
}

\author{
Syed Irfanul Hoque \\ Managing Trustee \\ Darul Irfan Research Institute (DIRI), Bangladesh \\ Nayeb Sajjadah Nasheen \\ Maizbhandar Darbar Sharif, Fatikchari, Chittagong, Bangladesh \\ E-mail: tasauf.darulirfan@gmail.com \\ Professor Dr. Asif Mahbub Karim, FCGIA \\ Dean, Binary Graduate School \\ Binary University of Management and Entrepreneurship, Malaysia \\ E-mail: drasifmkarim@gmail.com \\ Md. Rabiul Hossen \\ Lecturer \\ Department of English \\ Nanupur Laila Kabir University College, Bangladesh \\ Associate Member \\ Darul Irfan Research Institute (DIRI), Bangladesh \\ E-mail: tasauf.darulirfan@gmail.com

\section{Dina Arjumand} \\ Student \\ Department of "Urban \& Regional Planning" \\ Chittagong University of Engineering \& Technology \\ Associate Member \\ Darul Irfan Research Institute (DIRI), Bangladesh \\ E-mail: tasauf.darulirfan@gmail.com
}

\begin{abstract}
Telemedicine provides healthcare services to the patients through the adaptation of a telecommunication system, as opposed to the face-to-face conventional way of visiting a hospital and doctor's chamber. In the new-normal situation during COVID 19, telemedicine is a new way forward in the absence of conventional appointments with doctors to ensure regular health services. It is important to evaluate patients' satisfaction with service qualities and their perception of telemedicine service. The study proposed a conceptual framework based on the e-SERVQUAL model and TAM model to evaluate the service qualities and customers' satisfaction. Data has been collected through a telephone questionnaire survey from the patients through the psychiatric department who have received healthcare services provided by Maizbhanderi Foundation. Data has been analyzed using IBM SPSS Statistics version 23 according to the patients' responses on the
\end{abstract}


service qualities including responsiveness, reliability, information quality, empathy, ease of use, perceived usefulness, and their satisfaction with the telemedicine service. The study used Spearman Rank Co-relation to evaluate the co-relation of service qualities with customer satisfaction following the conceptual framework of the study. The result shows a positive co-relation of service qualities with customers' satisfaction. The study will help to determine the customers' satisfaction with service qualities using technology.

Keywords: e-SERVQUAL Model, TAM Model, Service Quality, Customer Satisfaction, Maizbhanderi Foundation.

\section{INTRODUCTION}

When longer life expectancy and costs have become a challenging issue to the present healthcare service system, telehealth service is providing a way to examine symptoms of patients by ensuring treatments, developed communication systems with quick responses. In developing countries, telemedicine services act as an adequate health care delivery system (Ayesha et al., 2020). Service Quality is very significant for the satisfaction of the customers, faith, and retention and so it has aroused huge controversy for decades (Baber, 2019). Customer satisfaction can be used as a thought in an overall assessment of the product, with value measurement obtained through experience and feelings that have been tested by the customers to the product (Tantarto et al., 2020) . It is very significant to have the acceptance of the patients for the successful implementations of telehealth services (Huang \& Liu, 2015). It is important to evaluate the service qualities of telemedicine service according to the opinion of the customers.

\section{PROBLEM STATEMENT}

The COVID-19 disease has a quick expansion around the world and it was first reported in December 2019 in China (Alam, 2020). Telemedicine is putting at the center stage of the digital health care solutions by the physician offices as the coronavirus pandemic has a swift shift in the health care delivery system (Chowdhury et al., 2021). According to this pandemic situation, Maizbhanderi Foundation has taken a step for providing healthcare services through virtual mode as telemedicine service. Customers' satisfaction determination is very important for any service or business company. If the customers don't have a good perception or satisfaction level, it is difficult for the company to run with the service. Evaluation of patients' satisfaction in the service quality of telemedicine is also important. The paper focuses on determining patients' satisfaction with the service qualities of telemedicine service provided by the Maizbhanderi Foundation. The study proposed a framework based on the e-SERVQUAL model and TAM model to evaluate the service qualities.

\section{OBJECTIVES}

- To evaluate the perception of the patients' satisfaction about the service qualities of the telemedicine service.

- To find out the relationship of service qualities with customer satisfaction.

\section{AN INTRODUCTION TO THE METHOD}

Telemedicine service is provided through video conferencing using the zoom platform or WhatsApp by Maizbhanderi Foundation. To understand the patients' perception of the telemedicine service, the study has conducted a telephone questionnaire survey. The researchers have developed a questionnaire based on the e-SERVQUAL model and TAM model including the service qualities; responsiveness, reliability, information quality, empathy, ease of use, perceived usefulness. Data 
were collected from 50 participants who are psychiatric patients. They have shared their perception of the telemedicine service and satisfaction level with this service provided by the Maizbhanderi Foundation. They also have told their interest to use the service in future.

\section{RESEARCH QUESTIONS}

- How was the perception of the patients about the service qualities?

- Are the patients overall satisfied with the service?

- Is there any relation between service qualities with customer satisfaction?

\section{Telemedicine Service}

\section{LITERATURE REVIEW}

Telemedicine service has got a solid foundation as a possible, reliable, and efficient technology that is provided by information technologies and telecommunications which are being amplified rapidly (Sood et al., 2007). The activities of our life and business can be overhauled with help of Information and Communication Technology (ICT) (Economic \& Review, 2020). Telemedicine service can ensure a decision under conditions of uncertainty and urgency which is considered as an emergency clinical activity (Haimi et al., 2018). Telemedicine service can ensure improved access to health care which enables patients to get care diagnosis and treatment from a remote area or at a distance (Kho et al., 2020)

\section{Service Quality in Telemedicine Service}

The measurement of service quality helps to evaluate the needs of consumers and also analyze the level of satisfaction of the customers with the provided services (Ghotbabadi et al., 2015). It is needed to understand how the company is running its business for several reasons (Akter, 2021). The significance of evaluating the perception of the patients is recognized by the healthcare providers and the satisfaction of the patient is used as an indicator of service quality (Gustke et al., 2000)

\section{E-Service Quality}

e-SQ which means electronic service quality is very significant by which the satisfaction level of the customers with the services of any business can be easily determined (Baber, 2019). The customers can be easily involved in the product development process by e-service quality which can offer the competitive advantages of online commercial companies (Santos, 2003). The service Quality model is much known in the market research field, but it is not applicable in online-based services. As telemedicine service was provided using an e-platform, authors have used the e-SERVQUAL model. By reviewing papers of the e-SERVQUAL model, authors have selected four qualities such as responsiveness, reliability, information quality, empathy which will be suitable for evaluating telemedicine service quality perfectly.

\section{TAM Model}

In the TAM model, two terms named perceived usefulness and perceived ease of use indicate the attitude of the customers to accept the new technology which can impulse customers' behavior, motive, and adoption of new technology (Mohtar et al., 2013). In the study of (Davis, 1989), authors have defined Perceived usefulness as the degree to which a person believes that his or her job performance would be enhanced by using a particular system. So, the author used this factor "perceived usefulness" of the TAM model to evaluate as telemedicine has enhanced their performance or provide access to the health care system. In the study of (Davis, 1989), Perceived ease of use is defined as the degree to which a person has a belief that they can use the system 
without any effort. In the study, the term "perceived ease of use" had been used to evaluate patients' comfort and easiness while using the telemedicine service.

\section{METHODOLOGY}

Participants: The participants of the study were both female and male with a total number of 50 . They are the participants of the telemedicine service program arranged by the Maizbhanderi Foundation. The program has been conducting since March 2020. The participants were Psychiatric patients.

Table 1. Participants according to Gender and Age

\begin{tabular}{|c|c|c|c|c|c|c|c|}
\hline \multirow{2}{*}{ Gender } & \multicolumn{9}{|c|}{ Age in year } & \multicolumn{2}{c|}{ Total Participants } \\
\cline { 2 - 8 } & $\mathbf{1 0 - 2 0}$ & $\mathbf{2 1 - 3 0}$ & $\mathbf{3 1 - 4 0}$ & $\mathbf{4 1 - 5 0}$ & $\mathbf{5 1 - 6 0}$ & F & \% \\
\hline Male & 1 & 8 & 5 & 7 & 1 & 22 & 44 \\
\hline Female & 4 & 2 & 9 & 7 & 6 & 28 & 56 \\
\hline Total & 5 & 10 & 14 & 14 & 7 & 50 & 100 \\
\hline
\end{tabular}

Data Collection: Data has been collected from the patients of the psychiatric department who have experience of the telemedicine service provided by the Maizbhanderi Foundation. A telephone questionnaire survey was conducted using 5 points Likert scale data as 5-strongly agree to 1strongly disagree. The questionnaire was prepared according to some factors of the e-SERVQUAL and TAM model. The sample size was 50.

The Procedure of Data Analysis: Data has been analyzed using SPSS (Statistical Package for the Social Sciences) according to participants' responses about the statements in the questionnaire. Patients' overall perception has been shown by using charts using Microsoft Excel 2019. Cronbach alpha has been done for checking the reliability among the statements in the questionnaire. Spearman rank correlation has been conducted using IBM SPSS version 23 for checking the correlation of service qualities according to patients' perception with their satisfaction level.

The Scale of The Questionnaire: The questionnaire was designed by following a 5-point Likert scale to know the opinion about their perception of service qualities of the telemedicine service and their satisfaction level with the service including future preference.

\begin{tabular}{|c|c|c|c|c|}
\hline $\mathbf{1}$ & $\mathbf{2}$ & $\mathbf{3}$ & $\mathbf{4}$ & $\mathbf{5}$ \\
\hline Strongly Disagree & Disagree & Moderately Agree & Agree & Strongly Agree \\
\hline
\end{tabular}

Proposed Research Framework: The research framework has been prepared based on the eSERVQUAL model and TAM model. The service qualities such as Information Quality, Responsiveness, Empathy, and Reliability are from the e-SERVQUAL model, and Ease of use and Perceived usefulness from the TAM model which are being used as independent variables, and customers' satisfaction as the dependent variable. 


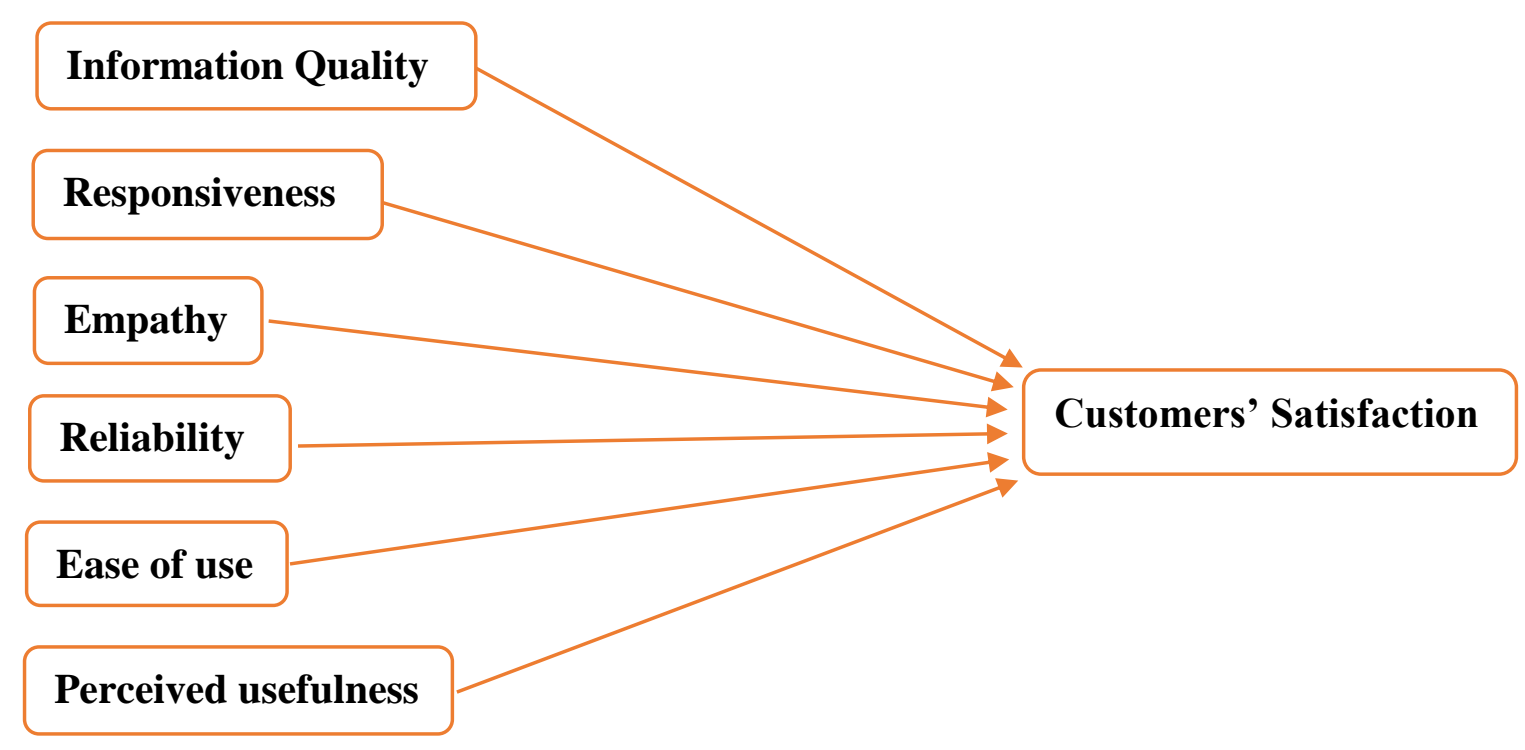

Figure 1. Proposed Research Framework

\section{RESULTS}

Reliability Test: Cronbach alpha method has been used for checking the reliability among the statements in the questionnaire which is a measure of internal consistency. The co-efficient value of Cronbach alpha has been found 0.87 which is considered very strong reliability among the statements in the questionnaire.

Patients' Perception of the Service Qualities of Telemedicine: For evaluating patients' perception of telemedicine service qualities, the responses of the participants are analyzed by determining some service qualities like Responsiveness, Reliability, Information Quality, Empathy, Ease of use, and Perceived usefulness.

Table 2. Perception of patients about Telemedicine service

\begin{tabular}{|c|c|c|c|c|c|c|}
\hline \multirow[b]{2}{*}{ Factors } & \multirow[b]{2}{*}{ Statements } & \multicolumn{5}{|c|}{ Responses (\%) } \\
\hline & & 1 & 2 & 3 & 4 & 5 \\
\hline \multirow[t]{2}{*}{ Responsiveness } & $\begin{array}{l}\text { Employees of the telemedicine service provide me perfect } \\
\text { schedule. }\end{array}$ & 4 & 2 & 20 & 12 & 62 \\
\hline & $\begin{array}{l}\text { Employees/doctors in the institution give me prompt } \\
\text { service. }\end{array}$ & 8 & 4 & 18 & 10 & 60 \\
\hline \multirow[b]{2}{*}{ Reliability } & $\begin{array}{l}\text { When this institution promises to do something by a } \\
\text { certain time, it does so. }\end{array}$ & 4 & 4 & 14 & 28 & 50 \\
\hline & $\begin{array}{l}\text { When I face a problem, consultants/doctors/assistants } \\
\text { show a sincere interest to solve the problem. }\end{array}$ & 4 & 8 & 12 & 24 & 52 \\
\hline \multirow[t]{2}{*}{$\begin{array}{l}\text { Information } \\
\text { Quality }\end{array}$} & $\begin{array}{l}\text { The information (such as on-screen messages, and other } \\
\text { documentation) provided was clear and easy to } \\
\text { understand. }\end{array}$ & 4 & 2 & 14 & 18 & 62 \\
\hline & It was easy to find the information I needed. & 0 & 2 & 22 & 16 & 60 \\
\hline Empathy & I have got individual care from this telemedicine service. & 2 & 4 & 20 & 28 & 46 \\
\hline
\end{tabular}




\begin{tabular}{|c|l|l|l|l|l|l|}
\hline & The employees of service understand my specific needs. & 2 & 4 & 16 & 28 & 50 \\
\hline \multirow{4}{*}{ Ease of use } & It was simple \& easy to use this system. & 2 & 4 & 20 & 22 & 52 \\
\cline { 2 - 8 } & I believe the service will be beneficial for me. & 4 & 0 & 16 & 32 & 48 \\
\cline { 2 - 7 } & I felt comfortable using this system. & 0 & 2 & 24 & 30 & 44 \\
\hline \multirow{2}{*}{$\begin{array}{c}\text { Perceived } \\
\text { Usefulness }\end{array}$} & $\begin{array}{l}\text { This Telemedicine service improves my access to } \\
\text { healthcare services. }\end{array}$ & $\begin{array}{l}\text { This service saves me time traveling to a hospital or } \\
\text { Doctors' chamber. }\end{array}$ & 2 & 16 & 26 & 52 \\
\hline
\end{tabular}

In the light of the patients' perception and responses, it has been found that most of the patients have agreed with the above statements under the service qualities of telemedicine service. Few have disagreed with the statements. The maximum number of patients have agreed that they have found the employees are responsive, reliable, have good information quality, Ease of use, and perceived usefulness.

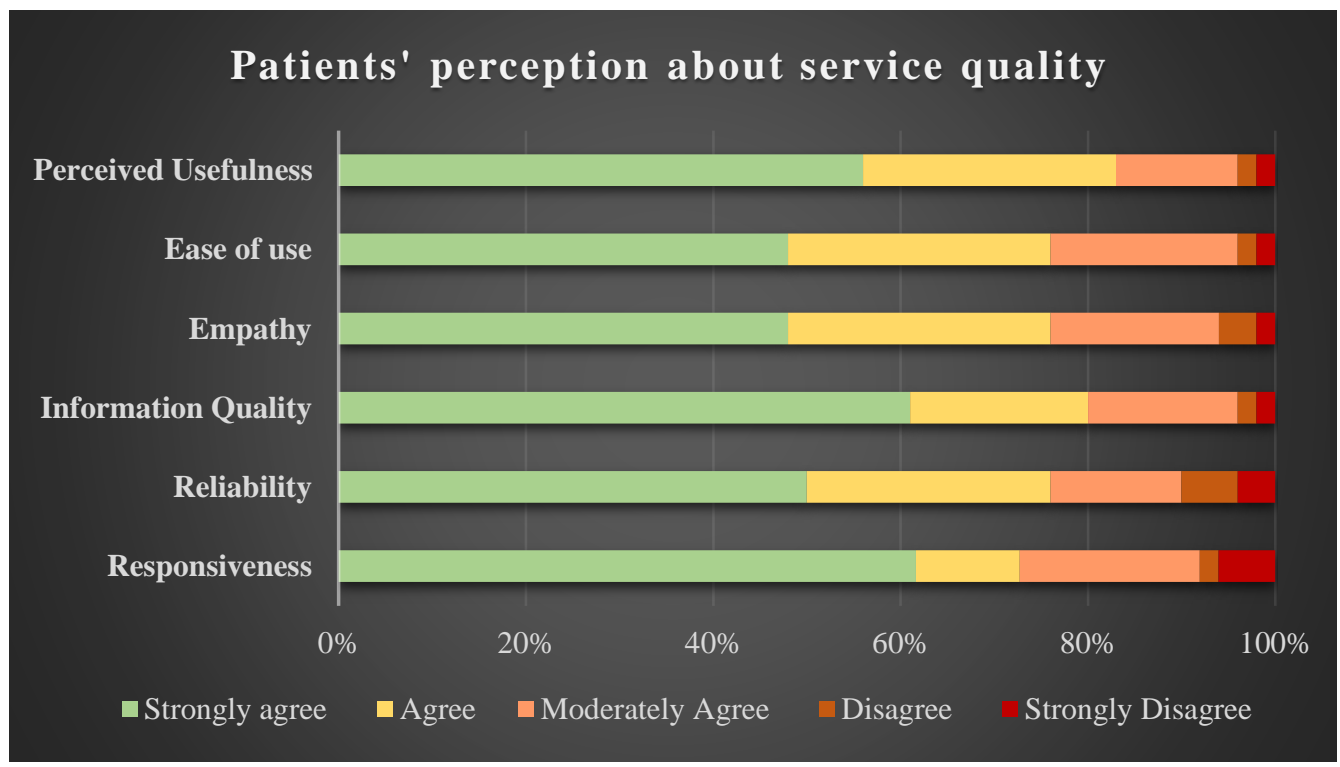

Figure 2. Patients' perception of service qualities

This value shows the mean value for the statements according to the service qualities such as perceived usefulness, Ease of use, Empathy, Information Quality, Reliability, Responsiveness. About $83 \%$ of Patients' said that this Telemedicine service is very useful. About $76 \%$ of the total patients agreed that it was easy to use the system. $76 \%$ of the patients agreed that the employees and doctors showed empathy while providing telehealth service. Around $78 \%$ of the patients agreed that the information provided by the employees are clear and understandable. $77 \%$ of the patients said that the telemedicine service is reliable for them. And $73 \%$ of the patients agreed that the employees are very responsive and sincere to them. 


\section{Customers' Satisfaction}

Lastly, patients' overall satisfaction was evaluated according to their responses. This factor was evaluated under the statements including overall satisfaction, the interest in using telemedicine in the future.

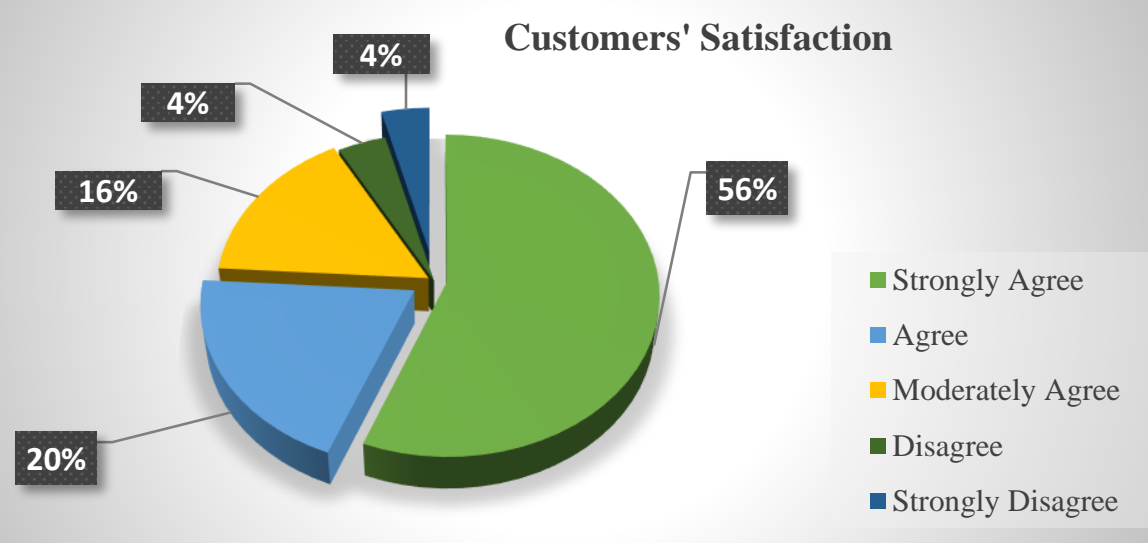

Figure 3. Patients' overall satisfaction

In the light of the above chart, a total of $76 \%$ are agreed that they are overall satisfied with the telemedicine service and they have preferred the service for the future also. Only $8 \%$ of the total patients are dissatisfied with the service.

\section{Spearman Rank Correlation}

Spearman rank correlation has been done for justifying the co-relation of the perception of the patients about the service qualities of telemedicine service with their satisfaction level.

Table 3. Correlation of service qualities with Patients' Satisfaction

\begin{tabular}{|c|c|c|c|c|c|c|c|c|}
\hline \multicolumn{2}{|c|}{ Spearman Rank Correlation } & \multirow{2}{*}{$\begin{array}{c}\text { Responsive } \\
\text { ness } \\
1.000\end{array}$} & \multirow{2}{*}{$\begin{array}{c}\text { Reliability } \\
.735^{* *}\end{array}$} & \multirow{2}{*}{$\begin{array}{c}\begin{array}{c}\text { Information } \\
\text { Quality }\end{array} \\
.517^{* *}\end{array}$} & \multirow{2}{*}{$\begin{array}{l}\begin{array}{l}\text { Empa } \\
\text { thy }\end{array} \\
.632^{* *}\end{array}$} & \multirow{2}{*}{$\begin{array}{c}\text { Ease } \\
\text { of } \\
\text { use }\end{array}$} & \multirow{2}{*}{$\begin{array}{c}\text { Perceived } \\
\text { Usefulness } \\
.525^{* *}\end{array}$} & \multirow{2}{*}{$\begin{array}{c}\begin{array}{c}\text { Customer } \\
\text { Satisfaction }\end{array} \\
.643^{* *}\end{array}$} \\
\hline \multirow{3}{*}{ Responsiveness } & $\begin{array}{l}\text { Correlation } \\
\text { Coefficient }\end{array}$ & & & & & & & \\
\hline & $\begin{array}{l}\text { Sig. (2- } \\
\text { tailed) }\end{array}$ & • & .000 & .000 & .000 & .000 & .000 & .000 \\
\hline & $\mathrm{N}$ & 50 & 50 & 50 & 50 & 50 & 50 & 50 \\
\hline \multirow{3}{*}{ Reliability } & $\begin{array}{l}\text { Correlation } \\
\text { Coefficient }\end{array}$ & $.735^{* *}$ & 1.000 & $.559^{* *}$ & $.711^{* *}$ & $.670^{* * *}$ & $.631^{* *}$ & $.793^{* *}$ \\
\hline & $\begin{array}{l}\text { Sig. (2- } \\
\text { tailed) }\end{array}$ & .000 & . & .000 & . 000. & .000 & .000 & .000 \\
\hline & $\mathrm{N}$ & 50 & 50 & 50 & 50 & 50 & 50 & 50 \\
\hline \multirow{3}{*}{$\begin{array}{c}\text { Information } \\
\text { Quality }\end{array}$} & $\begin{array}{l}\text { Correlation } \\
\text { Coefficient }\end{array}$ & $.517^{* *}$ & $.559^{* *}$ & 1.000 & $.526^{* *}$ & $.341^{*}$ & $.376^{* *}$ & $.544^{* *}$ \\
\hline & $\begin{array}{l}\text { Sig. (2- } \\
\text { tailed) }\end{array}$ & .000 & .000 & . & .000 & .015 & .007 & .000 \\
\hline & $\mathrm{N}$ & 50 & 50 & 50 & 50 & 50 & 50 & 50 \\
\hline
\end{tabular}




\begin{tabular}{|c|c|c|c|c|c|c|c|c|}
\hline \multirow{3}{*}{ Empathy } & $\begin{array}{l}\text { Correlation } \\
\text { Coefficient }\end{array}$ & $.632^{* *}$ & $.711^{* * *}$ & $.526^{* *}$ & 1.000 & $.478^{* * *}$ & $.443^{* *}$ & $.677^{* *}$ \\
\hline & $\begin{array}{l}\text { Sig. (2- } \\
\text { tailed) }\end{array}$ & .000 & .000 & .000 & ${ }^{\circ}$ & .000 & .001 & .000 \\
\hline & $\mathrm{N}$ & 50 & 50 & 50 & 50 & 50 & 50 & 50 \\
\hline \multirow{3}{*}{$\begin{array}{c}\text { Ease of } \\
\text { use }\end{array}$} & $\begin{array}{l}\text { Correlation } \\
\text { Coefficient }\end{array}$ & $.568^{* *}$ & $.670^{* *}$ & $.341^{*}$ & $.478^{* *}$ & 1.000 & $.706^{* *}$ & $.784^{* *}$ \\
\hline & $\begin{array}{l}\text { Sig. (2- } \\
\text { tailed) }\end{array}$ & .000 & .000 & .015 & .000 & . & .000 & .000 \\
\hline & $\mathrm{N}$ & 50 & 50 & 50 & 50 & 50 & 50 & 50 \\
\hline \multirow{3}{*}{$\begin{array}{l}\text { Perceived } \\
\text { Usefulness }\end{array}$} & $\begin{array}{l}\text { Correlation } \\
\text { Coefficient }\end{array}$ & $.525^{* *}$ & $.631^{* *}$ & $.376^{* *}$ & $.443^{* *}$ & $.706^{* * *}$ & 1.000 & $.651^{* *}$ \\
\hline & $\begin{array}{l}\text { Sig. (2- } \\
\text { tailed) }\end{array}$ & .000 & .000 & .007 & .001 & .000 & . & .000 \\
\hline & $\mathrm{N}$ & 50 & 50 & 50 & 50 & 50 & 50 & 50 \\
\hline \multirow{3}{*}{$\begin{array}{l}\text { Customers' } \\
\text { Satisfaction }\end{array}$} & $\begin{array}{l}\text { Correlation } \\
\text { Coefficient }\end{array}$ & $.643^{* *}$ & $.793^{* *}$ & $.544^{* *}$ & $.677^{* *}$ & $.784^{* *}$ & $.651^{* * *}$ & 1.000 \\
\hline & $\begin{array}{l}\text { Sig. (2- } \\
\text { tailed) }\end{array}$ & .000 & .000 & .000 & .000 & .000 & .000 & . \\
\hline & $\mathrm{N}$ & 50 & 50 & 50 & 50 & 50 & 50 & 50 \\
\hline
\end{tabular}

From Table 3, it has been found that all the service qualities are positively correlated with customers' satisfaction. The correlation between customers' satisfaction and responsiveness has a strong and positive correlation with the value of $r$ is 0.643 . Reliability has a positive and strong correlation with customers' satisfaction with the r-value 0.793 . The information quality is moderately co-related with customers' satisfaction having the value of $r, 0.544$. In light of the analysis, we can find the perception of the service qualities of telemedicine service has a strong and positive correlation with customers' satisfaction.

\section{DISCUSSION}

Due to the pandemic situation, the whole world is in turmoil (Asgor, 2021). Overall, in the new normal situation, the Telemedicine service is an alternative healthcare service for the patients. Information and Communication Technology (ICT) has been accepted as one of the main driving forces behind organizational competitiveness in the present-day business environment (Okon, 2018). It has enabled to provide telemedicine through e-platform. The service qualities of telemedicine were evaluated according to the perception and satisfaction of the patients. In the pandemic situation, telemedicine is an alternative and the best way for providing health care services to patients. In the light of the study, most of the patients are satisfied with the service provided by the Maizbhanderi foundation. And also they have preferred the telemedicine service for the future. According to patients' responses and preferences, we can decide to run the service in the future. This study will be helpful to determine customers' satisfaction with the service qualities according to the proposed framework based on the e-SERVQUAL model and TAM model. Few limitations have been found while conducting the survey. As it was a telephone questionnaire survey, many of the participants did not pick up the phone and also some of them switched off their phones. That's why we conducted the participants which were more than our sample size for getting responses according to our exact sample size. Few patients were dissatisfied with the telemedicine service. In the rural areas of Bangladesh, many people are not aware of the usage of ICT and also 
Telemedicine services. So, the study will be taking an approach to increase awareness about the telemedicine service. The persons who have the weakness to use the telemedicine service will be trained to use the service properly. According to the patients' perception, this service can be improved to make the patients satisfied.

\section{REFERENCES}

Akter, S. (2021). FINANCIAL FITNESS OF SELECTED PHARMACEUTICALS COMPANIES OF BANGLADESH: A COMPARATIVE ASSESSMENT. American Economic \& Social Review, 7(1), 10-24. https://doi.org/10.46281/aesr.v7i1.1171

Alam, M. S., Ali, M. J., Bhuiyan, A. B., Solaiman, M., \& Rahman, M. A. (2020). THE IMPACT OF COVID -19 PANDEMIC ON THE ECONOMIC GROWTH IN BANGLADESH: A CONCEPTUAL REVIEW. American Economic \& Social Review, 6(2), 1-12. https://doi.org/10.46281/aesr.v6i2.844

Hoque, S. I., Asgor, M. A., \& Islam, M. A. (2021). SOCIAL AWARENESS AND CREATIVITY ENHANCEMENT PROGRAM THROUGH E-LEARNING PLATFORM: A CASE OF MAIZBHANDER FOUNDATION'S MEDDHABIKASH PROGRAM, FATIKCHARI, BANGLADESH. American Economic \& Social Review, 7(1), 1-9. https://doi.org/10.46281/aesr.v7i1.1030

Ayesha, S., Shafiq, M., \& Kakria, P. (2020). Technology in Society Investigating acceptance of telemedicine services through an extended technology acceptance model ( TAM ). $\begin{array}{lllll}\text { Technology in } & \text { Society, }\end{array}$ https://doi.org/10.1016/j.techsoc.2019.101212

Baber, H. (2019). E- SERVQUAL and Its Impact on the Performance of Islamic Banks in Malaysia from the Customer' s Perspective. Journal of Asian Finance, Economics and Business, 6(1), 169-175. https://doi.org/10.13106/jafeb.2019.vol6.no1.169

Chowdhury, S. R., Sunna, T. C., \& Ahmed, S. (2021). Telemedicine is an important aspect of healthcare services amid COVID-19 outbreak: Its barriers in Bangladesh and strategies to overcome. International Journal of Health Planning and Management, 36(1), 4-12. https://doi.org/10.1002/hpm.3064

Davis, F. D. (1989). Perceived usefulness, perceived ease of use, and user acceptance of information technology. MIS Quarterly: Management Information Systems, 13(3), 319-339. https://doi.org/10.2307/249008

Uddin, M. G., \& Uddin, M. (2020). E-Government Development \& Digital Economy: Relationship. American Economic \& Social Review, 6(1), 39-54. https://doi.org/10.46281/aesr.v6i1.580

Ghotbabadi, A. R., Feiz, S., \& Baharun, R. (2015). Service Quality Measurements: A Review. International Journal of Academic Research in Business and Social Sciences, 5(2), 267286. https://doi.org/10.6007/ijarbss/v5-i2/1484

Gustke, S. S., Balch, D. C., West, V. L., \& Rogers, L. O. (2000). Patient satisfaction with telemedicine. Telemedicine Journal, 6(1), 5-13. https://doi.org/10.1089/107830200311806 
Haimi, M., Brammli-greenberg, S., Waisman, Y., \& Baron-epel, O. (2018). Physicians ' experiences, attitudes and challenges in a Pediatric Telemedicine Service. Pediatric Research, March. https://doi.org/10.1038/s41390-018-0117-6

Shu-Yun Yin \& Kuan-Kai Huang \& Jiunn-I Shieh \& Yu-Huei Liu \& Hsin-Hung Wu, (2015). Telehealth services evaluation: a combination of SERVQUAL model and importanceperformance analysis, Quality \& Quantity. International Journal of Methodology, Springer, 50(2), 751-766. https://doi.org/10.1007/s11135-015-0174-4

Kho, J., Gillespie, N. \& Martin-Khan, M. (2020). A systematic scoping review of change management practices used for telemedicine service implementations. BMC Health Serv Res 20, 815. https://doi.org/10.1186/s12913-020-05657-w

Mohtar, S., Hassan, M. G., \& Hasnan, N. (2013). A Study on Customer Interface Satisfaction by using TAM and SERVQUAL Dimension on the Use of Technology Job Search Website in Malaysia: A Case Study. International Journal of Business and Technopreneurship, 3(1), 85-104.

Okon, E. O. (2018). Female Labour Force, ICT and Growth Nexus in Nigeria. American Economic \& Social Review, 2(1), 33-41. https://doi.org/10.46281/aesr.v2i1.152

Santos, J. (2003). E-service quality: A model of virtual service quality dimensions. Managing Service Quality: An International Journal, 13(3), 233-246. https://doi.org/10.1108/09604520310476490

Sood, S., Mbarika, V., Jugoo, S., Dookhy, R., Doarn, C. R., Prakash, N., \& Merrell, R. C. (2007). What is telemedicine? A collection of 104 peer-reviewed perspectives and theoretical underpinnings. Telemedicine and E-Health, 13(5), 573-590. https://doi.org/10.1089/tmj.2006.0073

Tantarto, T., Kusnadi, D., \& Sukandar, H. (2020). Analysis of Service Quality Towards Patient Satisfaction (Comparative Study of Patients Using Telemedicine Application and Face to Face Consultation in Healthcare). European Journal of Business and Management Research, 5(5). https://doi.org/10.24018/ejbmr.2020.5.5.516

\section{Copyrights}

Copyright for this article is retained by the author(s), with first publication rights granted to the journal. This is an open-access article distributed under the terms and conditions of the Creative Commons Attribution license (http://creativecommons.org/licenses/by/4.0) 